\title{
Corporate Governance terhadap Tax Avoidance pada Perusahaan Manufaktur yang Terdaftar di Bursa Efek Indonesia
}

\author{
Farid Addy Sumantri ${ }^{1}$, Rr. Dian Anggraeni' ${ }^{2}$, Agus Kusnawan ${ }^{3}$ \\ Universitas Buddhi Dharma \\ farid_addy@yahoo.com
}

\begin{abstract}
Abstrak
Tujuan dari penelitian ini adalah untuk menguji bagaimana Pengaruh Dewan Direksi Independen, Kepemilikan Manajemen dan Komite Audit, terhadap Penghidaran Pajak pada Perusahaan Industri metal dan sejenisnya yang terdaftar di Bursa Efek Indonesia tahun 2012-2016. Pengukuran Tax Avoidance menggunakan CETR.

Sampel yang digunakan dalam penelitian ini sebanyak 45 sampel yang terdiri dari Sembilan perusahaan selama 5 tahun. Jenis penelitian yang mengunakan metode kuantitatif meupakan adalah dengan menggunakan pendekatan non random sampling. Teknis analisis yang digunakan adalah regresi linier berganda.

Hasil penelitian menunjukkan Proporsi Dewan Komisaris berpengaruh terhadap penghindaran pajak (tax avoidance) dengan nilai signifikannya sebesar $0,033<0,050$ ). Hasil penelitian ini menyimpulkan bahwa $\mathrm{H}_{1}$ yang diajukan dalam penelitian diterima dan terbukti, Komite Audit berpengaruh terhadap penghindaran pajak (tax avoidance) dengan nilai signifikannya sebesar $0,018<0,050$ ) dan Kepemilikan Manajemen tidak berpengaruh terhadap penghindaran pajak (tax avoidance) dengan nilai signifikannya sebesar 0,149>0,050).
\end{abstract}

Kata kunci: Dewan Komisaris Independen, Kepemilikan Manajemen, Komite Audit, CETR

\section{Pendahuluan}

Sumber pendapatan terbesar bagai Negara adalah pajak. Dalam APBN 2013 penerimaan yang target penerimaan yang bersumber dari pajak adalah sebesar 1.148,36 triliun rupiah $(76,5 \%)$ dari total pendapatan negara 1.502 triliun rupiah dalam APBN 2013 (Depkeu, 2013). Penerimaan tersebut digunakan Pemerintah untuk meningkatan kualitas pendidikan dan kesejahteraan rakyat, pembangunna infrastruktur pendorong pertumbuhan ekonomi indonesias, mendukung ketahanan dan keamanan. Begitu besarnya peran pajak bagi negara, pemerintah senantiasa berupaya untuk meningkatkan penerimaan dari sektor pajak

Fakta di lapangan menunjukkan fenomena berbeda dari yang diharapkan Pemerintah, dimana sampai saat ini pendapatan pemerintah dari sektor pajak belum maksimal, hal ini bisa dilihat dari penjelasan dari Direktur Jenderal (Dirjen) Pajak yang menyatakan, bahwa realisasi penerimaan pajak cenderung mengalami penurunan (Irma, 2013).

${ }^{1}$ Korespondensi: Farid Addy Sumantri. Universitas Buddhi Dharma. J1. Imam Bonjol No. 41 Karawaci Ilir, Tangerang. farid_addy@yahoo.com

${ }^{2}$ Korespondensi: Rr. Dian Anggraeni. Universitas Buddhi Dharma. Jl. Imam Bonjol No. 41 Karawaci Ilir, Tangerang. anggraeni.dian30@yahoo.com

${ }^{3}$ Korespondensi: Agus Kusnawan. Universitas Buddhi Dharma. Jl. Imam Bonjol No. 41 Karawaci Ilir, Tangerang. kusnawanagus71@gmail.com 


\section{eCo-Buss}

Tabel 1. Target dan Realisasi Penerimaan Pajak

\begin{tabular}{|r|r|r|r|}
\hline Tahun & $\begin{array}{c}\text { Target Penerimaan } \\
\text { Pajak (Rp) }\end{array}$ & $\begin{array}{c}\text { Realisasi Penerimaan } \\
\text { Pajak (Rp) }\end{array}$ & $\begin{array}{c}\text { Persentase (\%) } \\
\text { Penerimaan Pajak }\end{array}$ \\
\hline 2007 & 395,00 triliun & 382,22 triliun & 96,7 \\
\hline 2008 & 480,90 triliun & 494,10 triliun & 102,70 \\
\hline 2009 & 528,00 triliun & 515,73 triliun & 97,61 \\
\hline 2010 & 661,40 triliun & 649,04 triliun & 98,12 \\
\hline 2011 & 878,70 triliun & 873,90 triliun & 99,30 \\
\hline 2012 & $1.016,20$ triliun & $1.021,8$ triliun & 100,50 \\
\hline
\end{tabular}

Sumber: Badan Kebijakan Fiskal Kementerian Keuangan Republik Indonesia dan Badan Pusat Statistik Republik Indonesia (Dirjen Pajak, 2013)

Dari table diatas terlihat setiap tahunnya realisasi penerimaan pajak, terutama $\mathrm{PPh}$ tidak mencapai target hanya pada tahun 2008 dan 2012 target penerimaan pajak dapat tercapai, namun seiring dengan perkembangan waktu penerimaan pajak yang yang diterima masih menjukkan kondisi yang fluktuatif.

Salah satu indikasi yang menyebabkan penerimaan pajak tidak dapat dicapai kemungkinan adanya praktek penghindaran pajak (tax avoidance) yang dilakukan oleh Wajib Pajak. Tax Avoidance merupakan tindakan memperkecil beban pajak yang dilakukan wajib pajak dengan tidak melanggar undang-undang. Hal ini merupakan suatu tindakan efisiensi yang dilakukan perusahaan dengan cara yang legal/tidak melenggara ketentuan pajak, hal ini disebebkan adanya ketidaksempurnaan dalam Undang-Undang Perpajakan (Hanum dan Zulaikha, 2013).

Hasil survey yang dilakukan Hoque, et. al, (2011) menunjukan beberapa alasan mengapa wajib pajak tidak melakukan kewajiban untuk membayar pajak, hal ini sebabkan rendahnya kesadaran moral, tidak adanya/rendahnhya balas jasa dari pajak, adanya ketidakadilan yang diterima, keterbukaan dan pertanggungjawaban yang masih sangat rendah dari instansi pemerintah, terjadinya tindakan korupsi yang cukup tinggi, ada kelemahan dari sisi peraturan pajak dan peraturan keuangan, masih cuku[ tingginya biaya kepatuhan, serta masih cukup lemahnya penegakan hukum pajak, masih adanya pemungutan pajak yang tidak sesuai, lemahnya kemampuan dalam mendeteksi dalam penuntutan pelaksanaan ketentuan pajak yang tidak tepat, masih rendahnya kepercayaan wajib pajak kepada pemerintah, masih dirasakan cukup tingginya tarif pajak yang yang berlaku, dan masih terdapatnya kelemahan system administrasi pajak.

Penghindaran pajak (tax avoidance) adalah salah satu cara untuk menghindari pajak secara legal yang tidak melanggar peraturan perpajakan. Hal ini merupakan persoalan yang masih dirasakan cukup rumit dan unik. Sesuai ketentuan perpajakan yang berlaku di Indonesi tindakan penghindaran pajak yang dilakukan wajib pajak tidak melanggar aturan/hukum, sebaliknya hal ini tidak diinginkan oleh pemerintah. Pemerintah Indonesia sudah cukup banyak membuat peraturan dalam usaha mencegah adanya tindakan penghindaran pajak. Peraturan yang dibuat pemerintah salah satunya tentang transfer pricing, dimana diwajibkan adanya penerapan prinsip kewajaran dan kelaziman berusaha antara pihak-pihak yang mempunyai hubungan istimewa dalam malakukan transaksi usahanya (Perdirjen No. PER-43/PJ/2010, 2010).

Terjadinya krisis keuangan di Indonesia pada tahun 1997-1998, dirasakan peranan corporate governance (CG) merupakan sesuatu yang sangat penting agar kepercayaan masyarkat kepada dunia bisnis timbul kebali. Penerapan CG yang cukup baik bagi perusahaan-perusahaan yang mengelola dana masyarakat merupakan hal yang dirasakan cukup penting, khususnya untuk perusahaan yang terdaftar di bursa efek, perusahaan jasa keuangan, perusahaan manufaktur, dan perusahaan-perusahaan Pemerintah. Penerapan CG pada perusahaan-perusahaan tersebut 
diharapkan dapat menciptakan iklim berusaha yang lebi baik, sehingga dapat membantu pertumbuhan perekonomian di Indonesian secara makro.

Tata kelolah perusahaan (corporate governance) menjelaskan hubungan antara perusahaan dengan berbagai pihak-pihak yang berkepentingan (stakehlders) yang pada akhirnya dapat digunakan untuk menentukan arah kebijakan dan kinerja perusahaan (Haruman,2008). Corporate governancce juga mencakup struktur tujuan perusahaan yang ditetapkan, serta cara mencapai tujuan dan pemantauan kinerja. Keberhasilan penerapan CG tidak dapat dilepaskan dari unsru internal dan unsur eksternal perusahaan.

Semakin baik tingkat pengaruh corporate gorvernance akan semakin signifikan pengaruhnya terhadap tingkat penghindaran pajak yang dilakukan perusahaan, dengan tujuan memaksimalkan laba. Hasil penelitian yang dilakukan (Desai dan Dharmapala, 2005) ini membuktikan adanya tingkat pengaruh corporate governance mempunyai andil dalam tax planning perusahaan.

Kebanyakan dari Wajib Pajak orang pribadi maupun wajib pajak badan memiliki kecenderungan untuk meminimalkan pembayarab pajak kepada pemerintah, bahkan mereka kalau memungkinkan berusaha untuk tidak membayar pajak. Berdasakan peraturan pajak yang berlaku, bahwa setiap perusahaan yang didirikan di Indonesia atau melakukan kegiatan di Indonesia merupakan Wajib Pajak. Wajib Pajak orang pribadi maupun badan dituntut berdasarkan undung-undang untuk memenuhi kewajiban perpajakannya. Namu dalam praktiknya masih terdapat banyak hambatan, hal ini disebabkan para wajib pajak masih beranggapan bahwa pajak merupakan beban yang dapat mengurangi pendapatan, sehingga buat seminimal mungkin atau kalau memungkinkan untuk dihindari (Irma, 2013)

Kurniasih dan Annisa (2012), meneliti tentang Corporate Governance menunjukkan, dimana dari hasil penelitian yang dilakukan menunjukan adanya perbedaan kepentingan antara agent dan principal yang berkaitan dengan keadaan kondisi baik/tidaknya tata kelola suatu perusahaan pengaruhnya terhadap bagaiman pengambilan keputusan tentang masalah perpajakannya. Kurniasih dan Sari (2013), besar/kecilnya perusahaan akan menunjukan sehat/tidaknya keuangan perusahaan dalam aktivitas operasinya. Perusahaan yang memiliki modal yang cukup besar, akan menjadi pusat perhatian dari para stakeholders, sehingga akan membuat para manajer lebih patuh (compliances) atau cenderung agresif terhadap kewajiban perpajakan. Beberapa hal yang dapat dilakukan pihak manajer dalam melakukan penghidaran pajak, diantaranya menggunakan metode atau sistem yang adalah dalam standar dan diperbolehkan oleh undang-undang pajak, seperti penggunaan metode persediaan, metode penyusutan/ amortisasi aktiva tetap, pengadaan asset dengan cara leasing, dan menggunakan metode gross up.

\section{Literature Review/Related Works}

\section{Teori Agensi (Agency Theory)}

Teori keagenan menyatakan hubungan kontrak antara agent (pengelolah perusahaan) dengan principal (pemilik usaha). Agent tugasnya menjalakan aktivitas perusahaan untuk kepentingan pemilik perusahaan, sebalikan atas usaha yang dilakukan, makan pemilik perusahaan akan memberikan imbalan jasa kepada pengelolah perusahaan (Hendriksen dan Breda, 1992). Jensen dan Meckling (1976) mengemukakan bahwa hubungan antara agent dengan principal sebagai kontrak terhadap satu orang atau lebih untuk melakukan kegiatan jasa dan memberikan kewewenangan dalam pengambilan keputusan (Kurniasih \& Sari, 2013). Teori agensi mempengaruhi adanya political cost karena eksekutif melakukan penghindaran pajak (tax avoidance) untuk mendapatkan laba semaksimal mungkin, maka dengan itu eksekutif melakukan income smoothing .

Dalam penelitian ini memfokuskan pada hubungan antara manusia (perusahaan/fiskus) dengan sistem akuntansi (sistem tax avoidance). Dimana perusahaan melakukan tax avoidance dengan menggunakan sistem yang akuntansi ada pada perusahaan tanpa 
melanggar undang-undang perpajakan akan tetapi aktivitas penghindaran pajak tetap merugikan fiskus (pemerintah) karena dengan adanya penghindaran pajak (tax avoidance) dapat mengurangi APBN maka dari itu fiskus (pemerintah) akan melakukan pengawasan, megontrol penggunaan pajak yang dilakukan oleh perusahaan, Scott (2010)

\section{Corporate Governance}

Corporate governance merupakan salah satum bentuk sistem tata kelolah yang dapat menata dan mengontrol tindakan yang dilakukan manajer, dengan harapan dapat memperbaiki kinerja yang pada akhirnya diharapkan dapat meningkatkan nilai perusahaan untuk kepentingan stockholders (Herawati, 2008). Sedangkan Isgiarta dan Triatiarini (2005), mendefinisikan corporate governance sebagai sekumpulan aturan yang digunakan untuk mengatur hubungan antara stockholders, dan stakeholders yang berkaitan dengan hak dan kewajiban mereka atau dengan kata lain merupakan suatu bentuk sistem yang digunakan untuk mengatur dan mengendalikan perusahaan.

Dari beberapa definisi di atas dapat disimpulkan bahwa corporate governance adalah suatu mekanisme yang digunakan untuk mengatur dan mengontrol perusahaan melalui hubungan antara pemegang saham, pengurus/manajer perusahaan, pihak pemberi pinjaman, pemerintah, karyawan serta para yang berkepentingan baik intern maupun ekstern, sehingga dapat meningkatkan nilai perusahaan. Penerapan $C G$ yang baik dan benar diharpakan dapat menjaga keseimbangan antara tujuan yang akan dicapai perusahaan dan kepentingan masyarakat serta menjauhkan pengelolaah perusahaan yang kurang baik yang pada akhirnya akan menjadikan masalah bagi perusahaan (Dwitridinda dalam Hendra, 2012).

Hasil penelian yang dilakukan Anissa dan Kurniasih (2012), membuktikan tidak terdapat pengaruh komposisi dewan komisaris independen terhadap tax avoidance, tidak terbukti terdapat pengaruh signifikan dewan komisaris terhadap tax avoidance. Sebaliknya komite audit berpengaruh terhadap tax avoidance, dan kualitas audit berpengarug terhadap tax avoidance.

Jaya, Arafat dan Kartika (2013), membuktikan ; terdapat pengaruh komposisi kepemilikan saham institusi dan ukuran dewan direksi terhadap praktek penghindaran pajak, sebaliknya ukuran dewan direksi, kualitas audit dan konservtisme akuntansi tidak berpengaruh terhadap praktik penghindaran pajak.

Fadhilah (2011), membuktikan proporsi DKI dab komite audit tidak berpengaruh terhadap tax avoidance. Tebukti andayan pengaruh negatif kualitas audit terhadap tax avoidance. Kurniasih dan Annisa (2012) melakukan penelitian hubungan antara corporate governance terhadap tax avoidance dengan menggunakan variabel pengukuran kepemilikan institusional, dewan komisaris independen, dewan komisaris, komite audit dan kualitas audit yang dijadikan proksi dalam corporate governance, namun dalam penelitian itu tidak berhasil menemukan hubungan antara kepemilikan instistusional, dewan komisaris independen, dewan komisaris, dengan penghindaran pajak (tax avoidance), sebaliknya penelitiannya membuktikan terdapat pengaruh secara signifikan komite audit dan kualitas audit terhadap penghindaran pajak.

Penelitian yang dilakuan Darmawan dan Sukartha (2014), membuktikan bahwa corporate governance berpengaruh pada penghindaran pajak. Leverage tidak berpengaruh pada penghindaran pajak. ROA berpengaruh pada penghindaran pajak, dan ukuran perusahaan berpengaruh pada penghindaran pajak. Hartadinata (2013), membuktikan kepemilikan manajerial dan ukuran perusahaan berpengaruh secara signifikan terhadap tax aggressive, sedangkan kebijakan hutang tidak berpengaruh secara signifikan terhadap tax aggressive.

Darmawan dan Sukartha (2014), hasil penelitiannya membuktikan. corporate governance, ROA dan ukuran perusahaan berpengaruh terhadap tax avoidance. Sebaliknya penelitiannya 
tidak dapat membuktikan bahwa leverage berpengaruh pada penghindaran pajak. Penelitian Diantari dan Ulupui (2016) membuktikan terdapat pengaruh negative komite audit dan proporsi komisaris independen terhadap tax avoidance, sebaiknya penelitian yang dikalukan tidak dapat membukan proporsi kepemilikan institusional berpengaruh terhadap tax avoidance.

Eksandy (2016) membuktikan komisaris independen dan kualitas audit berpengaruh positif terhadap tax avoidance, sebaiknya tidak terdapat pengaruh komite audit terhadap tax avoidance. Dalam penelitian tersebut dilakukan juga pengujian secara simultan yang membuktikan terdapat pengaruh secara signifikan komisaris independen, komite audit dan kualitas audit terhadap penghindaran pajak (tax avoidance). Hasil penelitian yang dilakukan Pramudito dan Sari (2016) membuktikan tidak terdapat pengaruh konservatisme akuntansi dan ukuran dewan komisaris terhadap tax avoidance, sebalikanya kepemilikan saham manajerial berpengaruh negatif pada tax avoidance.

Mahulae dkk (2016) hasil penelitiannya menunjukkan kepemilikan institusional berpengaruh positif signifikan dan komite audit berpengaruh negatif terhadap tax avoidance. Sedangkan kepemilikan manajerial tidak berpengaruh signifikan terhadap tax avoidance.

\section{Perumusan Hipotesis}

\section{a. Pengaruh Dewan Komisaris Independen terhadap Tax Avoidance}

Semakin besar porsi dewan komisaris independen dapat bekerja secara efektif dalam melakukan pengawasan dan pengendalian terhadap direksi dan manajer dalam pengelolaan perusahaan. Hal yang harus dihindari keberadaan DKI bukan menjadi simbol semata untuk memenuhi ketentuan yang ditetapakan oleh Otoritas Jasa Keuangan (OJK). Dengah semakin besarnya porsi DKI dapat mempengaruhi kebijakan tax avoidance yang dilakukan oleh suatu perusahaan (Anisa dan Kurniasih, 2012).

Penelitian yang dilakukan Widyaningdyah (2002) dalam Antonia (2008) menunjukan bahwa proporsi dewan komisaris independen tidak berpengaruh terhadap manajemen laba, hal ini menujukan adanya manipulasi yang dilakukan pihak manajemen dalam menyajikan laporan keuangan. Hasil penelitian ini membuktikan adanya peluang bagi manajer untuk melakukan manajemen laba, Dengan tindakan tersebut diharapkan dapat menguntungkan perusahaan dari segi perpajakan.

Berdasarkan penjelasan diatas, maka hipotesis yang diajukan adalah sebagai berikut:

H1: Dewan komisaris independen berpengaruh terhadap penghindaran pajak.

\section{b. Pengaruh Kepemilikan Manajerial terhadap Tax Avoidance}

Para pemegang saham dengan jumlah yang cukup besar dapat mewakili kelompok yang memiliki kekuatan dalam hak suara di dalam RUPS, yang memiliki perusahaan, namun tidak mengelola perusahaan. Semakin besar jumlah persentase pemegang saham akan menunjukkan bahwa mereka memiliki pengaruh semakin besar untuk menentukan arah kebijakan perusahaan dan dapat memastikan bahwa kebijakan dibuat tersebut dapat memberikan keuntungan bagi mereka (Timothy: 2010).

Semakin besar porsi kepemilikan saham oleh manajerial, dapat dikatakan bahwa konsentrasi kepemilikan didalam perusahaan akan semakin kuat. Jumlah kepemilikan saham yang cukup besar ini akan menjadikan tata kelola perusahaan semakin baik, sebab semakin besarnya kekuatan pemilik untuk mengawasi pihak manajer dalam membuat arah kebijakan perusahaan. Pemegang saham terbesar pada perusahaan bisa dimanfaatkan secara optimal sebagai bentuk mekanisme pengawasan terhadapa masalah keagenan, yang pada akhirnya diharapkan dapat meningkatkan kinerja perusahaan (Timothy, 2010). 
Besarnya kepemilikan saham oleh manajerial, menunjukan adanya konsentrasi kepemilikan pada perusahaan cukup lemah, sehingga penerapan corporate governance akan lebih baik. Karena dengan banyak insentif, mereka akan lebih apresiasi terhadap kebijakan dan arah tujuan perusahaan untuk masa yang akan datang lebih baik, dan terdorong untuk melakukan pengawasan yang lebih baik terhadap pekerjaannya. Perusahaan dengan komposisi kepemilikan yang tidak terlalu tersebar tidak memiliki masalah dalam profitabilitasnya. Motivasi para manajerial dalam mendapatkan laba yang sebesar-besarnya, akan lebih memikirkan strategi pajak yang diambil akan lebih agresif. Dapat disimpulkan bahwa dengan semakin besar kepemilikan manajerial dalam perusahaan, penghindaran pajak akan semakin kecil (Timothy, 2010).

Perusahaan berusahaan untuk menaikan jumalah kepemilikan saham manajerial dalam rangka untuk menyetarakankan posisi manajer dengan para stockholders, sehingga manajer perusahaan dapat bertindak sesuai dengan harapan pemegang saham. Peningkatan persentase kepemilikan tersebut membuat manajer termotivas untuk berkerja lebih baik, meningkatkan bertanggung jawab terhadap perusahaan yang pada akhirnya dapat memberikan kesejahteraan para pemegang saham. Sebaliknya, kecilnya persentase saham yang dimiliki manajerial, maka manajer hanya terfokus pada pengembangan untuk meningkatkan perusahaan menjadi lebih besar. Hal ini tidak lain karena manajer yang juga memiliki kepemilikan saham cenderung mempertimbangkan kelangsungan usahanya sehingga tidak akan menghendaki usahanya diperiksa terkait masalah perpajakan sehingga tidak akan agresif dalam kebijakan perpajakannya (Hartadinata, 2013).

Berdasarkan uraian di atas, hipotesis yang dapat dikembangkan adalah:

H2: Kepemilikan manajerial berpengaruh terhadap Tax Avoidance

\section{c. Pengaruh Komite Audit terhadap Tax Avoidance}

Sriwedari (2009), yang menyatakan bahwa keberadaan komite audit yang fungsinya untuk meningkatkan integritas yang kredibilitas pelaporan keuangan agar dapat berjalan dengan baik. Komite audit perusahaan berpengaruh terhadap tax avoidance didasarkan beberapa alas an, yaitu; 1) kecilnya jumlah komite audit yang dimiliki oleh perusahaan, maka akan meminim bentuk pengendalian terhadap kebijakan keuangan, sehingga akan memberikan peluang yang cukup besar bagi manajemen untuk melakukan tindakan penghidaran pajak, sebaliknya semakin besar jumlah komite audit dalam perusahaan, akan meningkatkan pengendalian yang dilakukan terhadapat kebijakan keuangan pada perusahaan, sehingga akan memperkecil kesempatan tindakan manajemen untuk melakukan tindakan tax avoidance. 2) nama baik perusahaan perusahaan yang memiliki komite audit yang tidak sesuai dengan yang ditetapkan OJK akan mempengaruhi integritas dan kredibilitas keuangan perusahaan, sehingga memberikan peluang yang cukup besar kepada manajemen melakukan tax avoidance.

Berdasarkan uraian tersebut, maka hipotesis yang diajukan adalah sebagai berikut:

H3: Komite audit berpengaruh terhadap Tax Avoidance

\section{Metode Tulisan/Method}

\section{Objek Penelitian}

Dalam penelitian ini menggunakan laporan keuangan yang digunakan untuk pengkuran tax avoidance dan corporate governance yang diproxy dengan dewan komisaris independen, Kepemilikan kanajerial dan komite audit peneliti menggunakan laporan keuagan perusahaan manufaktur logam dan sejenisnya yang terdaftar di Bursa Efek Indonesia (BEI) periode 2012 sampai dengan 2016. 


\section{Metode Penelitian dan Sampe Penelitian}

Dalam penelitian ini, metode yang digunakan oleh penulis adalah pemilihan sampel berdasarkan pertimbangan (judgment sampling). Metode pengumpulan data atas dasar strategi kecakapan atau pertimbangan pribadi semata (Hamid, 2012).

Perusahaan industri manufaktur yang dipilih menggunkan pertimbangan sehingga data yang didapatkan homogen sehingga mencerminkan khusus terhadap satu jenis perusahaan yang dipilih. Peneliti menentukan sampel yang diambil dengan pertimbangan tertentu, sehingga sampel tidak diambil secara random sampling, tetapi peneliti yang menentukannya.

\section{Definisi dan Pengukuran Variabel}

Dalam penelitian ini digunakan berbagai variabel untuk melakukan analisis data, seperti variabel independen, dan variabel dependen. Variabel terikat dalam penelitian ini adalah tax avoidance, sedangkan variabel bebas dalam penelitian ini adalah dewan komisaris independen, kepemilikan manajerial dan komite audit. Adapun pengertian dan pengukuran variabel-variabel dalam penelitian ini adalah:

a. Dewan Komisaris Independen

Adalah banyaknya keanggotaan yang berasal dari luar perusahaan dibandingkan dengan keseluruhan anggota dewan yang dalam perusahaan.

$$
\text { DKI }=\frac{\text { Jumlah Anggota dari luar Perusahaan }}{\text { Jumlah Anggota Dewan Komisaris }} \times 100 \%
$$

b. Kepemilikan Manajerial

Menunjukan banyak porsi kepemilikan saham oleh pihak manajemen perusahaan terhadap keseluruhan jumlah saham beredar.

$$
\mathrm{KM}=\frac{\text { Jumlah Saham Manajemen }}{\text { Jumlah Saham yang beredar }} \times 100 \%
$$

c. Komite Audit

Dalam penelitian ini komite audit di ukur dengan menggunakan banyaknya jumlah komite adit dalam perusahaan (Diantari \& Ulupui, 2016).

d. Penghindaran pajak (tax avoidance).

Penghindaran pajak (tax avoidance) diproksikan dengan menggunakan (CETR). Besarnya jumlah kas yang dikeluarkan untuk membayar jumlah pajak perusahaan terhadap EBIT. Formula yang digunakan menghitung CETR sebagai berikut:

$$
\text { CETR }=\frac{\text { Pembayaran Pajak }}{\text { Laba sebelum Pajak }}
$$

Jika Cash ETR yang dihasilkan besar hal ini mengindikasikan rendahnya tingkat penghindaran pajak yang dilakukan perusahaan. Sebaliknya semakin kecil CETR mengindikasikan semakin tinggi tingkat penghidaran pajak yang dilakukan perusahaan

\section{Metode Analisis Data}

\section{Analisis Statistik Deskriptif}

Merupakan proses pengumpulan dan peringkasan data, serta upaya untuk menggambarkan berbagai karakteristik yang penting pada data yang telah terorganisir tersebut. Dalam pengujian ini akan menjelaskan kondisi suatu data yang dilihat dari nilai rata-rata (mean), 
standar deviasi, varian, maksimum, minimum, (Ghozali, 2012: 19).

\section{Uji Asumsi Klasik}

a. Uji Normalitas

Menurut Ghozali (2012), pengujian ini untuk menguji apakah dalam model regresi, variabel dependen dan variabel independen keduanya terdistribusi normal atau tidak. Model regresi yang baik adalah apabila keduanya mengambarkan datanya terdistribusi normal atau mendekati normal. Pengujian normalitas dapat dideteksi dengan melihat penyebaran titik pada sumber dari grafik normal probability plot. Jika tititk-titik menyebar disekitar garis diagonal maka dapat disimpulkan bahwa data tersebut berdistribusi normal.

Untuk mengetahui apakah suatu data tersebut normal atau tidak secara statistik maka dilakukan uji normalitas menurut Kolmogorov-Smirnov satu arah atau analisis grafis. Uji Kolmogorov-Smirnov dua arah dengan tingkat kepercayaan 5\% (Ghozali, 2012).

b. Uji Multikolinieritas

Menurut Ghozali (2012), penguuji multikolinieritas bertujuan untuk melihat apakah dalam regresi ditemukan ada atau tidaknya korelasi antar variabel bebas, model yang dapat digunakan dalam penelitian harus tidak terjadi adanya korelasi yang tinggi diantara variabel bebas. Apabila variabel independen saling berkorelasi maka variabel-variabel ini tidak orthogonal (nilai korelasi tidak sama dengan nol). Uji multikolinieritas dilihat dari nilai tolerance dan variance infiation factor (VIF).

Tolerance mengukur variabel bebas terpilih yang tidak dapat dijelaskan oleh variabel bebas lainnya. Jadi nilai tolerance yang rendah sama dengan nilai VIF tinggi (karena VIF $=1 /$ tolerance ) dan menunjukan adanya kolinearitas yang tinggi. Nilai cut off yang umum dipakai adalah nilai tolerance 0,10 atau nilai VIF yang berada dibawah nilai 10. Jadi multikolinearitas terjadi jika tolerance $<0,10$ atau nilai VIF $>10$.

c. Uji Heteroskedastisitas

Manurut Ghozali (2012), pengujian ini bertujuan melihat apakah dalam model regresi yang digunakan dalam penelitian terjadi ketidaksamaan varians dari residual satu pengamatan ke pengamatan lain. Jika varians dari residual satu pengamatan ke pengamatan lain tetap, maka disebut homoskedastisitas dan jika berbeda disebut heteroskedastisitas. Cara menguji ada tidaknya heteroskedastisitas yaitu dengan menggunakan uji park dan uji glejser, dimana tingkat signifikansinya harus di atas 5\%, maka tidak terjadi heteroskedastisitas. Selain itu dapat menggunakan analisis grafik pengujian scatter plot.

d. Uji Autokorelasi

Untuk menguji apakah dalam model regresi linier terdapat korelasi antara residual pada periode saat ini dengan residual periode sebelumnya. Model regresi yang baik adalah regresi yang bebas dari autokorelasi adalah dengan uji DW.

\section{Uji Hipotesis}

Tujuan pengujian hipotesis untuk menguji pengaruh parsial antara dewan komisaris independen terhadap cash effective tax rate (CETR), kepemilikan manajerial terhadap cash effective tax rate (CETR), dan komite audit terhadap cash effective tax rate (CETR) dengan $\alpha$ $=5 \%$. Teknis analisis penelitian ini menggunakan model regresi linier berganda sebagai berikut: 


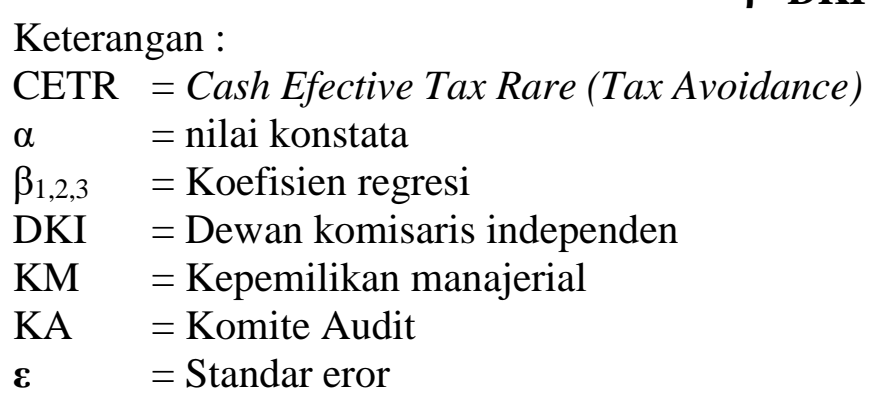

\section{Hasil}

\section{Analisis Statistik Deskriptif}

Statistik deskriptif menjelaskan nilai minimum, maksimum, mean, dan deviasi standar dari keempat variabel dalam penelitian ini. Metode analisis ini digunakan untuk mengetahui gambaran mengenai dewan komisaris independe, kepemilikan manajemen, komite audit, tax avoidance. Dari hasil pengujian statistik deskriptif atas keempat variable tersebut melalui data asli, maka diperoleh hasil sesuai dengan tabel berikut:

Tabel 2. Hasil Uji Statistik Deskriptif

\begin{tabular}{|l|r|r|r|r|r|}
\hline & $\mathrm{N}$ & Minimum & Maximum & Mean & $\begin{array}{r}\text { Std. } \\
\text { Deviation }\end{array}$ \\
\hline Penghidaran Pajak & 45 & .08 & 2.63 & .4253 & .58518 \\
Dewak Komisaris & 45 & .25 & .50 & .3747 & .08841 \\
Independen & 45 & .20 & 3.09 & 1.1144 & .63891 \\
Kepemilikan Manajemen & 45 & .25 & .60 & .4287 & .10343 \\
Komite Audit & 45 & & & & \\
Valid N (listwise) & & & & \\
\hline
\end{tabular}

Sumber : Data Diolah

Berdasarkan pada tabel 4.8 diatas menunjukan bahwa jumlah sample atau $\mathrm{N}$ data valid yang akan diteliti adalah 45 sampel. Dari data variabel penghindaran pajak (tax avoidance) yang merupakan model dari variabel dependen diperoleh rata-rata sebesar 0,4253 dengan nilai terendah sebesar 0,08 dan nilai tertinggi sebesar 2,63 dengan stadar deviasi sebesar 0,58518. Semakin kecil nilai akrual suatu perusahaan menunjukan bahwa tingkat penghindaran pajak tersebut semakin tinggi, begitu juga sebaliknya.. Berdasarkan hasil uji statistik tersebut diatas, dapat dismpulkan bahwa sebagian perusahaan sampel yang diteliti tingkat penghidaran pajak yang dilakukan cukup rendah Variabel dewan komisaris mempunyai nilai minimum 0,25 dan nilai maximum sebesar 0,50. Nilai rata-rata variabel dewan komisaris sebesar 0,3747 dengan standar deviasi sebesar 0,08841. Berdasarkan hasil tersebut dapat disimpulkan pengawasan yang dilakukan sudah cukup maksimal. Dengan semakin maksimalnya pengawasan yang dilakukan dewan komisaris terhadap pihak manajemen dalam menyusun laporan keuangan, sehingga dapat mengrungi pihak manajemen melakukan penghindaran pajak.

Variabel kepemilikan manajemen memiliki nilai minimum 0,20 dan nilai maximum sebesar 3,09. Nilai rata-rata variabel kepemilikan manajemen adalah sebesar 1,1144 dengan standar deviasi sebesar 063891. Berdasrkan data diatas sebagian besar kepemilikan manajemen terdapat saham perusahaan masih cukup kecil, maka pengawasan yang dilakukan terhadap fihak manajemen 
masih belum maksimal, sehingga fihak manajemen cederung melakukan penghindaran pajak (tax avoidance).

Variabel komite audit mempunyai nilai minimum 0,25 dan nilai maximum sebesar 0,60. Nilai rata-rata variabel komite adalah sebesar 0,4287 dengan standar deviasi sebesar 0,10343. Berdasarkan hasil pengujian tersebut dapat disimpulkan sebagaian besar komite audit yang terdapat dalam perusahaan sebagian besar telah malakukan peranannya dengan baik, sehingga dapat memperkecil fihak manajemen untuk melakukan penghindaran pajak.

\section{Uji Asumsi Klasik}

Uji asumsi klasik digunakan untuk menguji, apakah model penelitian yang digunakan dalam penelitian ini layak diuji atau tidak. Uji asumsi klasik digunakan untuk memastikan bahwa normalitas, autokorelasi, heteroskedastisitas dan multikolinearitas tidak terdapat dalam model yang digunakan dan data yang dihasilkan terdistribusi normal. Jika keseluruhan syarat tersebut terpenuhi, berarti bahwa model yang digunakan telah memenuhi syarat untuk digunakan (Gujarati dalam Ardianti, 2012). Uji asumsi klasik, dapat dijabarkan sebagai berikut:

\section{Uji Normalitas}

Pengujian dilakukan untuk mengetahui apakah data terdistribusi normal atau tidak. Pengujian normalitas menggunakan Uji Kolmogorov - Smirnov. Adapun pengujian total sampel data disajikan pada tabel berikut ini:

Tabel 3 Hasil Uji Normalitas

One-Sample Kolmogorov-Smirnov Test

\begin{tabular}{|ll|r|}
\hline & & \multicolumn{2}{|l|}{$\begin{array}{l}\text { Unstandardi } \\
\text { zed } \\
\text { Residual }\end{array}$} \\
\hline $\mathrm{N}$ & & 45 \\
Normal Parameters $^{\mathrm{a}}$ & Mean & .0000000 \\
& Std. Deviation & .56736428 \\
Most Extreme Differences & Absolute & .308 \\
& Positive & .308 \\
& Negative & -.213 \\
Kolmogorov-Smirnov Z & & 2.065 \\
Asymp . Sig. (2-tailed) & & .360 \\
\hline
\end{tabular}

a. Test distribution is Normal.

Sumber : Data yang diolah

Dari tabel di atas menunjukan nilai Asymp Sig sebesar 0,360 dan nilai variable independen yang memiliki signifikan lebih besar dari nilai 0,05 , dari pengujian disimpulkan bahwa data yang digunakan dalam penelitian ini berdistribusi normal.

\section{Uji Multikolinearitas}

Pengujian ini dimaksudkan untuk mengetahui apakah terdapat interkorelasi sempurna antara variabel-variabel independen yang digunakan dalam penelitian ini.Uji ini dilakukan dengan Tolerance Value dan Variance Inflation Factor (VIF). Adapun hasil uji multikolinearitas pada penelitian ini dapat dilihat pada tabel di bawah ini: 
Tabel 4. Hasil Uji Multikolinearitas

Coefficients $^{\mathrm{a}}$

\begin{tabular}{|cl|r|r|}
\hline \multirow{2}{*}{ Model } & & \multicolumn{2}{|c|}{ Collinearity Statistics } \\
\cline { 2 - 4 } & & Tolerance & VIF \\
\hline 1 & $\begin{array}{l}\text { Dewak Komisaris } \\
\text { Independen }\end{array}$ & .880 & 1.137 \\
& Kepemilikan & .813 & 1.230 \\
& Manajemen & .905 & 1.105 \\
\hline
\end{tabular}

a. Dependent Variable: Penghidaran Pajak

Sumber : Data yang diolah

Berdasarkan tabel di atas, tolerance value $>0,10$ dan VIF $<10$, sehingga dapat disimpulkan bahwa seluruh variabel independen tidak terdapat hubungan multikolinearitas dan dapat digunakan dalam peneletian ini.

\section{Uji Heterokedastisitas}

Dalam penelitian ini digunakan diagram scatterplot. Untuk mengetahui tidak terjadinya $\mathrm{t}$ heterokedastisitas, maka titik-titik tersebut tersebar acak dan tidak membentuk pola tertentu. Adapun hasil uji heterokedastisitas dalam penelitian ini disajikan pada gambar 3 berikut ini:

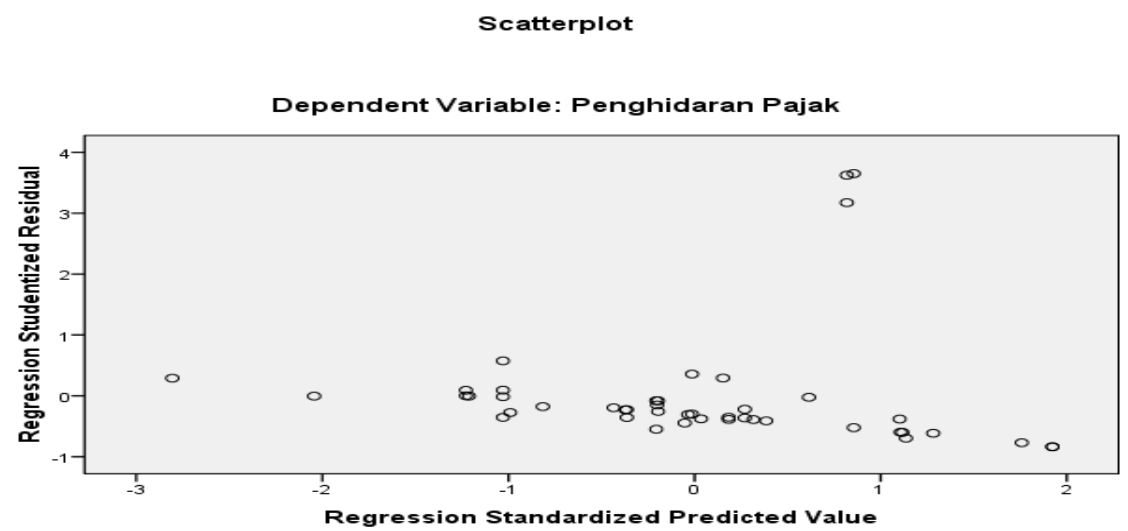

Gambar 1 Scatterplot

Apabila dilihat dari grafik scatterplot, terlihat titik-titik menyebar secara acak, serta tersebar di atas dan di bawah angka 0 pada sumbu Y, sehingga dapat diambil kesimpulan tidak terdapat gejala heteroskedastisitas.

\section{Uji Autokorelasi}

Pengujian autokorelasi menggunakan Durbin-Watson untuk mencari ada tidaknya autokorelasi dalam penelitian yaitu dengan membandingkan nilai $\mathrm{DW}_{\text {hitung }}$ dengan $\mathrm{DW}_{\text {tabel. }}$. Dari hasil pengujian yang dilakukan dapat dilihat pada tabel di bawah ini: 
Tabel 5. Hasil Uji Autokorelasi

Model Summary ${ }^{b}$

\begin{tabular}{|c|r|}
\hline Model & \multicolumn{2}{|c|}{ Durbin-Watson } \\
\hline 1 & \\
\hline
\end{tabular}

a. Predictors: (Constant), Komite Audit,

Dewak

Komisaris Independen, Kepemilikan

Manajemen

b. Dependent Variable: Penghidaran Pajak

Sumber : Data yang diolah

Berdasarkan hasil pengujian autokorelasi pada tabel di atas diketahui nilai $\mathrm{DW}_{\text {hitung }}$ sebesar 1,847. Dari hasil tabel Durbin Watson diketahui $\mathrm{n}=45, \mathrm{k}=3$ dengan $\alpha=0,05$ diperoleh nilai $\mathrm{DW}_{\text {tabel }} \mathrm{d}_{\mathrm{L}}=1,3832$ dan $\mathrm{d}_{\mathrm{u}}=1,6662$. Berdasarkan data tersebut diketahui nilai nilai dari uji Durbin Watson adalah $1,6662<1,847<2,3338$, sehingga dapat disimpulkan bahwa variabel yang digunakan dalam penelitian ini tidak terjadi autokorelasi.

\section{Analisis Koefisien Determinasi (Adjusted $R$ Squre)}

Koefisien determinasi $\left(\mathrm{R}^{2}\right)$ bertujuan mengukur seberapa jauh kemampuan model dalam menerangkan variabel dependen. Adapun nilai adjusted $\mathrm{R}^{2}$ dari hasil perhitungan menggunakan SPSS 20 terlihat pada tabel di bawah ini:

Tabel 6. Hasil Uji Koefisien Determinasi (Adjusted $\mathbf{R}^{2}$ )

\begin{tabular}{|c|c|c|c|c|}
\hline Model & $\mathrm{R}$ & R Square & $\begin{array}{l}\text { Adjusted R } \\
\text { Square }\end{array}$ & $\begin{array}{l}\text { Std. Error of } \\
\text { the Estimate }\end{array}$ \\
\hline 1 & $.245^{\mathrm{a}}$ & .060 & .509 & .58776 \\
\hline
\end{tabular}

Pajak

b. Dependent Variable: Penghidaran

Sumber : Data yang diolah

Nilai Adjusted R Square sebesar 0,509 dan semakin mendekati 1 yang berarti menunjukkan variabel independen dewan komisaris independen, kepemilikan manajerial, dan komite audit dapat dapat mejelaskan variabel dependen penghindaran pajak (tax avoidance).

\section{Uji Hipotesis}

Pengujian ini bertujuan untuk mengetahui besaran nilai koefisien masing-masing variable dewan komisaris independen, kepemilikan manajemen, dan komite audit, berpengaruh terhadap penghindaran pajak (tax avoidance). Pengujian ini dilakukan dengan membandingkan nilai signifikansi t yang ditunjukkan oleh Sig dari t pada tabel 4.13 dengan tingkat signifikansi yang diambil, dalam hal ini 0,05 . Jika nilai signifikan ( $p$-value) $<0,05$, maka variabel independen berpengaruh terhadap variabel dependen. Hasil Uji t dapat dilihat dari tabel dibawah ini: 
Tabel 7. Hasil Uji T

Coefficients ${ }^{\mathbf{a}}$

\begin{tabular}{|c|c|c|c|c|c|}
\hline \multirow[b]{2}{*}{ Model } & \multicolumn{2}{|c|}{$\begin{array}{l}\text { Unstandardized } \\
\text { Coefficients }\end{array}$} & \multirow{2}{*}{$\begin{array}{l}\text { Standardized } \\
\text { Coefficients } \\
\text { Beta }\end{array}$} & \multirow[b]{2}{*}{$\mathrm{T}$} & \multirow[b]{2}{*}{ Sig. } \\
\hline & B & Std. Error & & & \\
\hline (Constant) & 1.213 & .550 & & 2.207 & .033 \\
\hline $\begin{array}{l}\text { Dewak Komisaris } \\
\text { Independen }\end{array}$ & -.852 & 1.069 & -.129 & -.797 & .030 \\
\hline $\begin{array}{l}\text { Kepemilikan } \\
\text { Manajemen }\end{array}$ & -.071 & .154 & -.077 & -.459 & .049 \\
\hline Komite Audit & -.910 & .901 & -.161 & -1.010 & .018 \\
\hline
\end{tabular}

a. Dependent Variable: Penghidaran pajak

Sumber : Data Diolah

a. Dewan Komisaris Independen berpengaruh terhadap Penghindaran Pajak (Tax Avoidance)

Hasil pengujian hipotesis pertama yang diajukan dalam penelitian ini diperoleh nilai koefisien variabel dewan komisaris independen dengan signifikansi sebesar 0,030 atau lebih kecil dari 0,05, maka dapat disimpulkan bahwa hipotesa diterima dan terbukti.

b. Kepemilikan Manajemen berpengaruh terhadap Penghindaran Pajak (Tax Avoidance)

Hasil pengujian hipotesis kedua yang diajukan dalam penelitian ini diperoleh nilai koefisien variabel kemepilikan manajemen dengan signifikansi sebesar 0,049 atau lebih kecil dari 0,05, maka hipotesa diterima dan terbukti.

c. Komite Audit berpengaruh terhadap Penghindaran Pajak (Tax Avoidance)

Hasil pengujian hipotesis ketiga yang diajukan dalam penelitian ini diperoleh nilai koefisien regresi untuk variable komite audit dengan signifikansi sebesar 0,018 atau lebih kecil dari 0,05, maka dapat disimpulkan hipotesa diterima dan terbukti.

\section{Implikasi Hasil Penelitian}

Berdasarkan hasil penelitian yang telah dijelaskan sebelumnya, maka akan dilakukan pembahasan terhadap hasil penelitian untuk memperoleh gambaran ebih lanjut setiap hasil pengujian sesuai dengan aspek-aspek yang mendasarinya.

\section{a. Pengaruh Dewan Komisaris Independen terhadap penghindaran pajak (tax avoidance}

Berdasarkan pengujian hipotesis bahwa variabel komite audit independen berpengaruh terhadap penghindaran pajak (tax avoidance). Hasil penelitian ini menemukan bukti bahwa terdapat pengaruh negatif dewan komisaris independen terhadap tax avoidance.

Hasil penelitian ini sejalan dengan hasil penelitian yang dilakukan Diantari dan Ulupui (2016), yang membuktikan terdapat pengaruh negatif dewan komisaris independen terhadap tax avoidance, sedangkan hasil penelitian Eksandy (2016) yang membukan terdapat pengaruh positif dewan komisaris independen terhadap tax avoidance.

Namun hasil penelitian ini tidak sejalan dengan penelitian yang dilakukan Fadhillah (2011), Anisa dan Kurniasih (2012) yang membuktikan besarnya komposisi dewan komisaris independen tidak berpengaruh terhadap tax avoidance. 
Hal ini menjelaskan bahwa semakin banyak jumlah dewan komisaris independen yang ada dalam perusahaan mampu melakukan pengawasan yang cukup ketat terhadap pihak manajemen dalam menunyusun laporan keuangan. Hal ini menunjukan semakin besar jumlah dewan komisaris independen yang ada dalam perusahaan mampu menekan pihak manajemen untuk melakukan tax avoidance.

b. Pengaruh Kepemilikan Manajemen terhadap penghindaran pajak (tax avoidance

Berdasarkan hasil pengujian membuktikan adanya pengaruh kepemilikan manajemen terhadap tax avoidance. Hasil penelitian ini menemukan bukti bahwa besar/kecil porsi kepemilikan saham manajemen dapat menurunkan tindakan penghindaran pajak (tax avoidance). Hasil penelitian ini sejalan dengan penelitian Mahulae, dkk (2016), dimana kepemilikan tidak memiliki pengaruh terhadap tax avoidance, sebaliknya penelitian tidak sejalan dengan penelitian Hartdinata (2013), Pramudito dan Sari (2016) yang membuktikan terdapat pengaruh kempemilikan manajerial terhadap tax avoidance.

Dari hasil pengujian hipotesis tersebut dapat dijelaskan bahwa dalam penelitian ini proporsi kepemilikan saham oleh pihak manajerial yang lebih kecil dari total saham perusahaan. Dari sampel yang diteliti untuk kepemilikan manajerial masih dibawah 30\%, hanya satu peruhaan yaitu PT. Gunawa Dianjaya pada tahun 2015 dan 2016 jumlah kepemikan sahama menajerial 87,33\%. Hal tersebut memungkinkan bahwa pihak manajerial tidak memiliki hak yang cukup besar dalam pengambilan keputusan perusahaan, sehingga pihak manajerial tidak memiliki kesempatan serta wewenang yang besar dalam perusahaan untuk melakukan tindakan penghidaran pajak (tax avoidance).

\section{c. Pengaruh Komite Audit terhadap penghindaran pajak (tax avoidance}

Berdasarkan hasil pengujian hipotesis ketiga variabel komite Audit berpengaruh terhadap penghindaran pajak (tax avoidance). Hasil penelitian ini membuktikan bahwa adanya pengaruh komite audit terhadap tax avoidance. Hasil penelitian ini sejalan dengan hasil penelitian Fadhilah (2011) dan Mahulae, dkk (2016), menunjukkan bahwa komite audit berpengaruh terhadap penghindaran pajak dibandingkan etnis pribumi. Sedangkan hasil penelitian Diantari dan Ulupui (2016) membuktikan komite Audit berpengaruh negatif terhadap tax avoidance.

Namun hasil penelitian berlawanan dengan penelitian Eksandy (2016), dimana komite audit tidak berpengaruh terhadap tax avoidance.

Arah negatif mengindikasikan bahwa bahwa banyak sedikitnya jumlah komite audit dalam perusahaan tidak menjamin komite audit dapat menguranngi/memperkecil tindakan peghindaran pajak yang mungkin dilakukan oleh pihak manajemen perusahaan. Penambahan komite audit yang dilakukan perusahaan dapat saja dilakukan untuk memenuhi jumlah minimal yang telah ditetapkan OJK mengenai panduan untuk pembentukan komite audit.

\section{Simpulan}

Dari hasil pengujian hipotesis terhadap seluruh variabel diperoleh kesimpulan, sebagai berikut

1. Dewan Komisaris Independen berpengaruh terhadap penghindaran pajak (tax avoidance) dengan nilai signifikan sebesar $0,033<0,050$ ). Hasil penelitian ini membuktikan bahwa $\mathrm{H}_{1}$ diterima dan terbukti.

2. Kepemilikan Manajemen tidak berpengaruh terhadap penghindaran pajak (tax avoidance) dengan nilai signifikan sebesar $0,149>0,050$ ). Hasil penelitian ini menyimpulkan bahwa $\mathrm{H}_{2}$ yang diajukan dalam penelitian ditolak dan tidak terbukti. 
3. Komite Audit berpengaruh terhadap penghindaran pajak (tax avoidance) dengan nilai signifikannya sebesar $0,018<0,050$ ). Hasil penelitian ini menyimpulkan bahwa $\mathrm{H}_{3}$ diterima dan terbukti.

\section{Daftar Pustaka}

Annisa, Nuralifmida Ayu. "Pengaruh Corporate Governance terhadap Tax Avoidance (Studi Pada Perusahaan Terdaftar di BEI Tahun 2008)". Skripsi Fakultas Ekonomi Universitas Sebelas Maret Surakarta, 2011

Boediono, Gideon, SB. "Kualitas Laba: Studi Pengaruh Mekanisme Corporate Governance dan Dampak Manajemen Laba dengan Menggunakan Analisis Jalur". Solo: Simposium Nasional Akuntansi VIII, 2005

Batara Wiryo Pramudito, Maria M. Ratna Saru "Pengarug Konservatisme Akuntansi, Kepemilikan Manajeriak dan Ukuran Dewan Komisaris Terhadapat Tax Avoidance", EJurnal Akuntansi Udayana, Vol. 12. 3 Desember 2015.

Darmawati. "Hubungan Corporate Governance dan Kinerja Perusahaan". Simposium Nasional Akuntansi VII, Denpasar, 2004

Dyreng, Scott. et. al. The Effects of Executives on Corporate Tax Avoidance”. Social Science Research Network, 2010

Eksandy Arry, "Pengaruh Komisaris Independen, Komite Audit dan Kualitas Audit terhadap Penghindaran Pajak (Tax Avoidance)", Competitive Jurnal Akuntansi dan Keuangan, Vol,1, 2017.

Erni, Masdupi. "Analisis Dampak Struktur Kepemilikan Pada Kebijakan Hutang dalam Mengontrol Konflik”. Keagenan Journal Ekonomi dan Bisnis Indonesia, Vol. 20, No. 1: 57-69. 2005

Fadhilah, Rahmi. "Pengaruh Good Corporate Governance terhadap Tax Avoidance (Studi Empiris Pada Perusahaan Manufaktur yang Terdaftar di BEI 2009-2011)”. Jurnal Fakultas Ekonomi Universitas Negeri Padang. 2014

Ghozali, Imam. "Aplikasi Analisis Multivariat dengan Pogram SPSS". Semarang: Badan Penerbitan Universitas Diponegoro. 2011

Haruman, Tendi. "Pengaruh Struktur Kepemilikan terhadap Keputusan Keuangan Dana Nilai Perusahaan". Pontianak: Simposium Nasional Akuntansi XI. 2008

Hamid, Abdul. "Buku Panduan Penulisan Skripsi. Jakarta: Fakultas Ekonomi dan Ilmu Sosial Universitas Islam Negeri Syarif Hidayatullah. 2012

Hartadinata, Okta. S. "Analisis Pengaruh Kepemilikan Manajerial, Kebijakan Hutang, dan Ukuran Perusahaan Terhadap Tax Aggressiveness pada Perusahaan manufaktur di Bursa Efek Indonesia Periode tahun 2008-2010" Jurnal Ekonomi dan Bisnis No.3 Desember 2013

Herawati, Vinola. "Peran Praktek Corporate Governance Sebagai Moderating Variabel dari Pengukuran Earnings Management terhadap Nilai Perusahaan”. Pontianak: SNA XI. 2008

Hendra P. Irawan dan Aria Fahmita, "Pengaruh Kompensasi Manajemen dan Corporate Governance Terhadap Manajemen Pajak Perusahaan”. Artikel. Universitas Indonesia. Tahun 2012.

Ilyas, B Wirawan dan Richard Burton. "Hukum Pajak”. Jakarta: Salemba Empat. 2006

I Gede Hendy Darmawan, I Made Sukartha, "Pengarug Coporate Gavernace. Leverate, ROA dan Ukuran Perusahaan pada Penghindaran Pajak", Juarnal Akuntansi, Vol. 19 No,1, Tahun 2014

Isgiarta, Midiastuty dan Triatiarini. "Analisa Hubungan Mekanisme Corporate Governance dan Indikasi Manajemen Laba”. Simposium Nasional Akuntansi VI. IAI. 2005 
Jao, Robert, Corporate governance, Ukuran Perusahaan, dan Leverage Terhadap Manajemen Laba Perusahaan manufaktur Indonesia, Jurnal Akuntansi \& Auditing, Volume 8/No. 1/November 2011.

Kurniasih, Tommy dan Sari, Maria M. Ratna. Pengaruh Return On Asset, Leverage, Corporate Governance, Ukuran Perusahaan, dan Kompensasi Rugi Fiskal Pada Tax Avoidance, Buletin Studi Ekonomi, Volume 18, No.1, Februari 2013.

Mahulae Endari Endang, Dudi Pratomom Anisa Nurbaiti "Pengaruh Kepemilikan Institusi, Kepemilikan Manajerial dan Komite Audit Terhadao Tax Avoidance". e-Proceeding of Management, Vol 3 No.2, Agustus 2016

Martina, Venti Yustianti. "Peran Corporate Governance dalam Meminimalkan Praktik Manajemen Laba”. Jurnal Manajemen Indonesia, Vol. 9, No. 3. 2009

Midiastuty, P.P. dan Machfoedz, M. "Analis hubungan mekanisme Corporate Governance dan indikasi Manajemen Laba". Simposium Nasional Akuntansi VI, Surabaya. 2003

Moh'd M.A., et. al. "The Impact of Ownership Structure on Corporation Debt Policy: A TimeSeries Cross-Sectional Analysis". The Financial Riview, 33, pp. 85-98. 1998

Nugroho, Agung. "Strategi Jitu Memilih Metode Statistic Penelitian dengan SPSS". Yogyakarta: Andi. 2005

Okta S. Hartadinata, “Analisis pengaruh kepemilikian manajerial, kebijakan utang, dan ukuran perusahaan terhadap Tax Aggressive pada perusahaan manufaktur di BEI tahun 20082010”, e-Jurnal Unair.ac.id, 2013

Putri, Destika Maharani. "Pengaruh Karakteristik Komite Audit terhadap Manajemen Laba". Skripsi S1, Tidak Dipublikasikan. Universitas Diponegoro Semarang. 2011

Putu Rista Diantari dan IGK Agung Ulupui (2016), "Pengaruh Komite Audit, Proporsi Komisaris Independen, dan Proporsi Kepemilikan Institusional terhadap Tax Avoidance”, E-Jurnal Akuntansi Unviversitas Udayana, 22.4, 2016.

Pramudito, B.W dan M.M.R. Sari, "Pengaruh Konservatisme Akuntansi, Kepemelikan Manajerial dan Ukuran Dewan Komisari Terhadap Tax Avoidance” Skripsi, Universitas Udayana Bali, 2015.

Santoso, Singgih. “Masterin SPSS Versi 17”. Jakarta: PT. Elex Media Komputindo. 2009

Siallagan, Hamongan dan Machfoeds, Mas'ud. "Mekanisme Corporate Governance, Kualitas Laba dan Nilai Perusahaan”. Simposium Nasional Akuntansi IX, Padang. 2006

Siswantaya, I Gede. "Mekanisme Corporate Governance dan Manajemen Laba Studi Pada Perusahaan-Perusahaan yang Terdaftar di Bursa Efek Jakarta”. Tesis. Fakultas Ekonomi, Universitas Diponegoro Semarang. 2007

Scott et al. 2010. Long Run Corporate Tax Avoidance. The Effects of Excecutives on Corporate Tax Avoidance.

Suandy, Erly. "Perencanaan Pajak”. Jakarta: Salemba Empat. 2008

Sumarsan, Thomas. "Perpajakan Indonesia”. Jakarta: Indeks. 2010

Surya, Indra dan Yustiavandana, Ivan. "Penerapan Good Corporate Governance: Mengesampingkan Hak-Hak Istimewa Demi Kelangsungan Usaha”. LKPMK Fakultas Hukum Universitas Indonesia. 2008

Tommy Kurniasih dan Maria M. Ratna Sari, "Pengaruh Return On Asset, Leverage,Corporate Governance, Ukuran Perusahaan, dan Kompensasi Rugi Fiskal Pada Tax Avoidance" Buleting Studi Ekonomi, Tahun 2013.

Ujiyantho, Arif Muh. dan B.A. Pramuka. "Mekanisme Corporate Governance, Manajemen Laba dan Kinerja Keuangan”. Simposium Nasional Akuntansi X, Makasar. 2007

Waluyo, "Perpajakan Indonesia". Edisi 9. Jakarta: Salemba empat. 2010

Zain, Mohammad. “Manajemen Perpajakan”. Jakarta: Salemba Empat. 2003. 